\title{
Medicine and Money
}

\section{Human tissue for sale: what are the costs?}

\author{
Deborah Josefson, San Francisco \\ debdoc@aol.com
}

This article was published in BMJ 2000;321:658

Several academic hospitals in the United States are forming partnerships with biotechnology companies to provide human tissue for use in research, treatment, or drug development. This series of arrangements raise wide legal and ethical issues. Harvard University's Beth Israel Deaconess Medical Center in Boston, Massachusetts and the Duke University Medical Center in Durham, North Carolina are among the latest academic hospitals to form partnerships with biotechnology companies for the purpose of providing human tissue for use in research, treatment, and drug development. Both of these institutions have entered into agreements with Ardais, a genomics startup company, which will bank the tissue, collect data, and sell both the data and the tissue to interested parties. Patients undergoing surgery at these medical centers will be asked to sign permission forms that enable the medical center to send leftover pathology specimens to biotechnology companies.

Ardais intends to create a massive tissue catalogue, allowing researchers to place Internet orders for tissue samples from patients with the specific diseases they are studying. The company will maintain the confidentiality of patients by assigning a numeric code to the donated tissue and clinical information so that medical researchers will not be able to contact the patient.

Although there is a great need for centralized, data-linked tissue banks, and surplus tumor tissue is usually discarded anyway, such partnerships raise interesting ethical, financial, and legal questions. Chief among these concerns are issues of privacy, the commodification of body parts, and whether there is any financial or moral obligation to compensate the tissue donors for contributing the raw material for research and development.

Tissue donors, because of the anony-

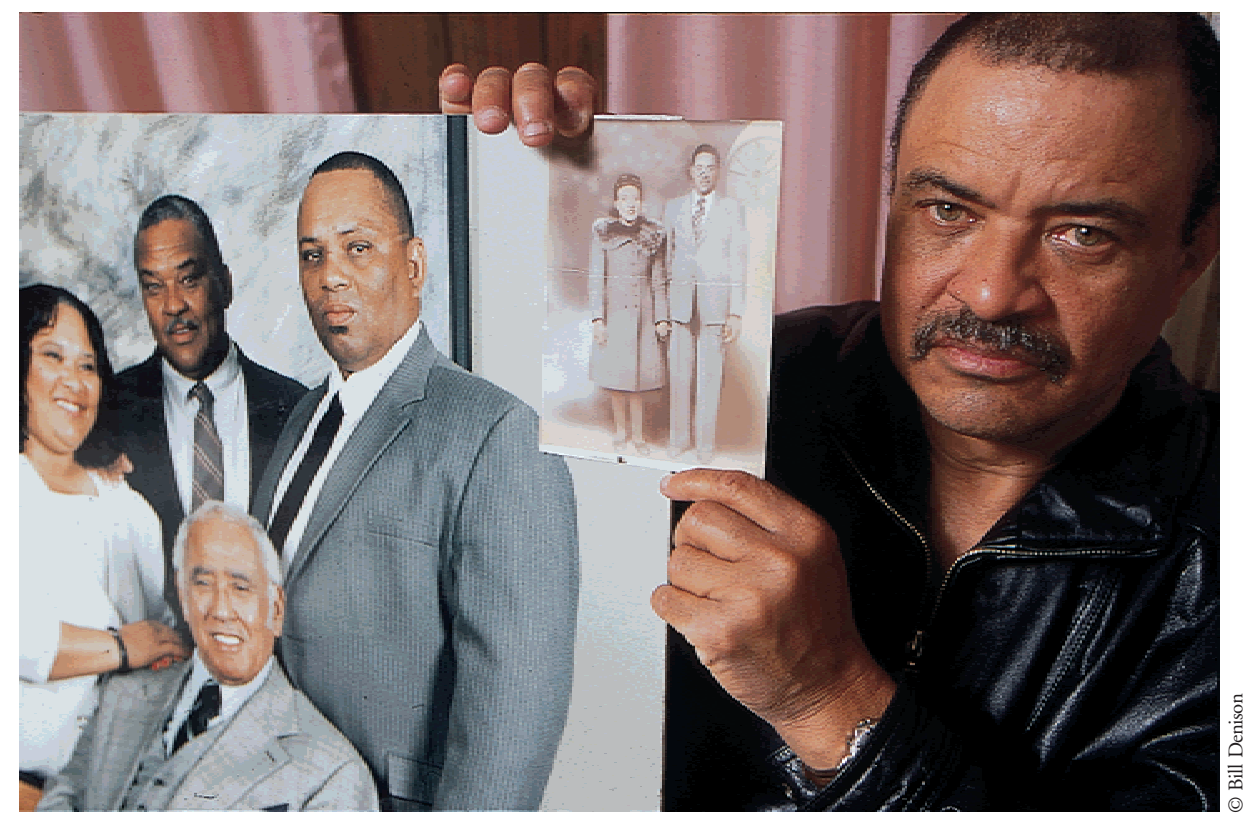

David Lacks holds a portrait of his mother, whose cells have been used without permission

mous nature of the donation, may not see any medical or therapeutic benefit from the donation. Will cash-strapped hospitals be tempted to enter into these agreements in order to buttress their financial status?

Tissue banking and joint academic and industrial ventures are not new, but awareness of some of the legal, financial, and ethical implications that they raise is. Many academic hospitals routinely bank frozen tissue of rare and interesting tumors. Usually these tissues are studied in-house as a means to aid in diagnosis, and often the tissue is shared with researchers from other departments and hospitals. Increasingly, shrewd or misguided patients request that their tissue be sent to a company involved in in vitro tissue chemotherapy sensitivity testing or genetic testing.

The biomedical community also has a legacy, however, of using such tissues with- out the patient's the knowledge. Often, these uses begin innocently, such as in an attempt to investigate disease, but even then ethical considerations arise. Henrietta Lacks, for example, was a poor, young woman who died of cervical cancer in 1951. When she was a patient at Johns Hopkins Hospital in the early 1950s, a sample of her cervical cells was sent to an in-house researcher who was trying to grow human cells in culture. Although Ms Lacks died nearly 50 years ago, her cells continue to live on as the HeLa cell line. They have contributed to countless biomedical discoveries and can be ordered from tissue culture supply catalogues. Despite this contribution to scientific exploration, neither she nor her family gave permission for these cells to be used, and the family was never compensated for any profits made from them.

Public policy regarding tissue donation and use is confused. Trafficking of vital or- 
gans for profit is illegal and is specifically proscribed under the National Organ Transplant Act of 1984. When it comes to other tissues, however, the rules are hazy. Officially, sales of other tissues are also illegal, but tissue banking is big business and the law is readily sidestepped by invoking "processing and handling fees" so that the tissue itself is not officially sold.

Profit-making tissue banks have been the beneficiaries of increased organ donations. According to the American Association of Tissue Banks, tissue donation has increased by $172 \%$ in the past 5 years. This increase is largely due to the fact that such organisations are informed when a patient dies.

In the United States, when a patient dies in a hospital or nursing home, doctors must ask if the family consents to organ and tissue donation. This action is mandated by the National Organ and Tissue Donation initiative of 1999. Whereas vital organs have a finite life span and must be transplanted within hours, tissues such skin, corneas, tendon, bone, and heart valves can be harvested later and cryopreserved. Thus, more tissues than organs are donated. A good proportion of these body parts are processed and sold for profit and become such items as bone putty and collagen. The tissue donor's family is usually not aware of the destination of the body parts and is not financially compensated-nor is it clear that the family should be. Many believe that the transplant and donor pool would shrink if the public realized the commercial potential.
The commodification of body parts and the widening of the gap between rich and poor, with the poor selling their tissues, is also a repugnant scenario. Interestingly, donors have long been able to sell their blood, sperm, and eggs in the United States, perhaps because these are seen as self-replenishing or surplus body parts.

Clearly, a bank of human tissues is needed to enable further research, diagnosis, and therapeutic development. The ability to relate the molecular findings of the Human Genome Project to clinically relevant material and data depends on ventures such as those involving Ardais and academic centers. The bioethical questions and repercussions of these partnerships, however, continue to be problematic.

\section{Which medical Web site} should your patients trust? Yours, of course.

\section{Get Your Physician Web Site Today. FREE, from Medscape.}

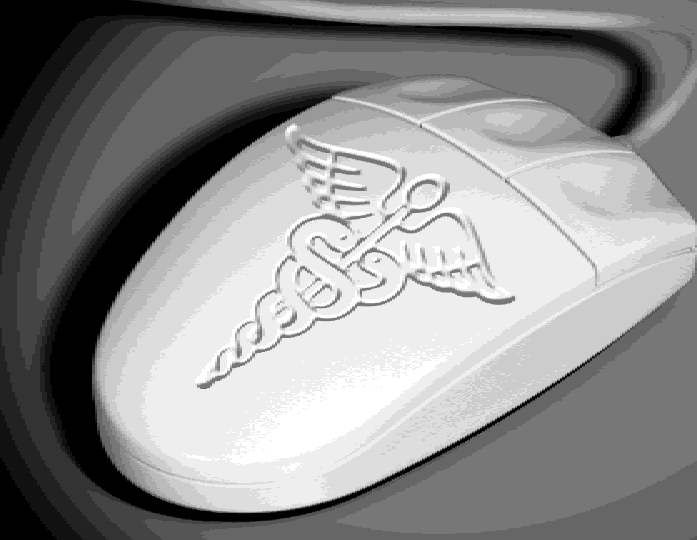

Medscape $\square$ Register with Medscape for free at www.medscape.com

$\square$ Create your FREE Physician Web Site by going to www.medscape.com/PWS/WJM where you'll find instructions and easy-to-use templates.

Need help? Call us at (800) 661-9789.

NEW on Medscape! Medscape welcomes to its Publishers' Circle Western Journal of Medicine. Selected articles and Med.Pix now available via Medscape! 